\title{
Inward-Rectifying Potassium $\left(\mathrm{K}_{\mathrm{ir}}\right)$ Channels Regulate Pacemaker Activity in Spinal Nociceptive Circuits during Early Life
}

\author{
Jie Li, Meredith L. Blankenship, and Mark L. Baccei \\ Pain Research Center, Department of Anesthesiology, University of Cincinnati Medical Center, Cincinnati, Ohio 45267
}

Pacemaker neurons in neonatal spinal nociceptive circuits generate intrinsic burst firing and are distinguished by a lower "leak" membrane conductance compared with adjacent nonbursting neurons. However, little is known about which subtypes of leak channels regulate the level of pacemaker activity within the developing rat superficial dorsal horn (SDH). Here we demonstrate that a hallmark feature of lamina I pacemaker neurons is a reduced conductance through inward-rectifying potassium $\left(\mathrm{K}_{\mathrm{ir}}\right)$ channels at physiological membrane potentials. Differences in the strength of inward rectification between pacemakers and nonpacemakers indicate the presence of functionally distinct $\mathrm{K}_{\mathrm{ir}}$ currents in these two populations at room temperature. However, $\mathrm{K}_{\mathrm{ir}}$ currents in both groups showed high sensitivity to block by extracellular Ba ${ }^{2+}\left(\mathrm{IC}_{50} \sim 10 \mu \mathrm{M}\right)$, which suggests the presence of "classical" $\mathrm{K}_{\mathrm{ir}}\left(\mathrm{K}_{\mathrm{ir}} 2 . \mathrm{x}\right)$ channels in the neonatal $\mathrm{SDH}$. The reduced $\mathrm{K}_{\mathrm{ir}}$ conductance within pacemakers is unlikely to be explained by an absence of particular $\mathrm{K}_{\mathrm{ir}} 2 . \mathrm{x}$ isoforms, as immunohistochemical analysis revealed the expression of $\mathrm{K}_{\mathrm{ir}} 2.1, \mathrm{~K}_{\mathrm{ir}} 2.2$, and $\mathrm{K}_{\mathrm{ir}} 2.3$ within spontaneously bursting neurons. Importantly, $\mathrm{Ba}^{2+}$ application unmasked rhythmic burst firing in $\sim 42 \%$ of nonbursting lamina I neurons, suggesting that pacemaker activity is a latent property of a sizeable population of SDH cells during early life. In addition, the prevalence of spontaneous burst firing within lamina I was enhanced in the presence of high internal concentrations of free $\mathrm{Mg}^{2+}$, consistent with its documented ability to block $\mathrm{K}_{\mathrm{ir}}$ channels from the intracellular side. Collectively, the results indicate that $\mathrm{K}_{\mathrm{ir}}$ channels are key modulators of pacemaker activity in newborn central pain networks.

\section{Introduction}

Spontaneous activity is essential for the proper maturation of neuronal circuits in the CNS, via its wide-ranging effects on neurotransmitter phenotype (Borodinsky et al., 2004), axonal pathfinding (Hanson et al., 2008), synapse formation (Gonzalez-Islas and Wenner, 2006), and the synchronization of firing across networks (Tritsch et al., 2007). Spontaneous network activity during early development can reflect a variety of underlying mechanisms, such as transient synaptic connections, gap junction coupling, GABAergic depolarizations, and the presence of pacemaker neurons (Blankenship and Feller, 2010), which have been previously defined as cells exhibiting intrinsic, oscillatory burst firing (Ramirez et al., 2004).

Within the neonatal spinal cord, pacemaker-like cells have been described in the ventral horn (Tazerart et al., 2007, 2008), where they are proposed to contribute to rhythmogenesis in lo-

Received Sept. 12, 2012; revised Dec. 21, 2012; accepted Dec. 22, 2012.

Author contributions: J.L., M.L.BI., and M.L.Ba. designed research; J.L., M.L.Bl., and M.L.Ba. performed research; J.L., M.L.Bl., and M.L.Ba. analyzed data; J.L., M.L.BI., and M.L.Ba. wrote the paper.

This work was supported by National Institutes of Health Grants NS060858 and NS072202 (M.L.Ba.). We thank Drs. Peter Szucs and Boris Safronov for technical advice regarding the infrared LED illumination of the intact spinal cord and Elizabeth Kritzer for assistance with confocal image analysis. We also thank Drs. Judith Strong and JunMing Zhang for helpful feedback regarding this manuscript.

Correspondence should be addressed to Dr. Mark L. Baccei, Pain Research Center, Department of Anesthesiology, University of Cincinnati Medical Center, 231 Albert Sabin Way, Cincinnati, 0 H 45267. E-mail: mark.baccei@uc.edu. DOI:10.1523/JNEUROSCI.4365-12.2013

Copyright $\odot 2013$ the authors $\quad 0270-6474 / 13 / 333352-11 \$ 15.00 / 0$ comotor networks (Brocard et al., 2010). Pacemaker neurons were also recently identified within lamina I of the newborn superficial dorsal horn (SDH) (Li and Baccei, 2011), which receives direct projections from nociceptive $\mathrm{A} \delta$ - and C-fiber sensory neurons (Light and Perl, 1979; Sugiura et al., 1986) and represents a key component of the ascending pain pathway. Pacemakers constitute $\sim 25-30 \%$ of the lamina I population during the first days of life (Li and Baccei, 2011) and are similar to intrinsically bursting neurons in other regions of the CNS (Del Negro et al., 2002) in that they are distinguished by a high ratio of persistent, voltage-gated $\mathrm{Na}^{+}$conductance to "leak" membrane conductance. This has been attributed to a significantly higher membrane resistance compared with adjacent nonbursting lamina I neurons ( $\mathrm{Li}$ and Baccei, 2011). Leak conductance potently regulates neuronal excitability across the CNS and can result from any channel being open at the resting membrane potential (Goldstein et al., 2001). This raises the possibility that altered leak channel function and/or expression may predispose a subset of neurons to function as pacemakers within the immature $\mathrm{SDH}$.

Inward-rectifying potassium $\left(\mathrm{K}_{\mathrm{ir}}\right)$ channels are strong candidates to modulate intrinsic burst firing within the newborn spinal cord. Low $\mathrm{K}_{\mathrm{ir}}$ conductance in neurons can drive spontaneous firing by depolarizing the membrane potential above the threshold to recruit persistent voltage-gated $\mathrm{Na}^{+}$currents (Leao et al., 2012), which are essential for rhythmic bursting within lamina I (Li and Baccei, 2011). In addition, the block of $\mathrm{K}_{\mathrm{ir}}$ currents by metabotropic inputs unmasks endogenous burst firing in the ma- 
jority of deep dorsal horn neurons from the adult spinal cord (Derjean et al., 2003). Unfortunately, little is known about the underlying basis for leak membrane conductance in developing SDH neurons. As a result, the degree to which $\mathrm{K}_{\mathrm{ir}}$ channels regulate spontaneous pacemaker activity within newborn spinal pain circuits remains unknown.

Here we demonstrate that a reduced conductance through "classical" $\mathrm{K}_{\mathrm{ir}}$ channels near physiological potentials is a critical determinant of intrinsic burst firing in spinal lamina I neurons during early life. This implies that the number of functional pacemaker neurons within the developing SDH network is not constant. It is instead dependent on $\mathrm{K}_{\mathrm{ir}}$ function, which may be modulated by both the extracellular and the intracellular environments.

\section{Materials and Methods}

All experiments adhered to animal welfare guidelines established by the University of Cincinnati Institutional Animal Care and Use Committee.

Preparation of spinal cord slices. Sprague Dawley rats of either sex were deeply anesthetized with sodium pentobarbital $(30 \mathrm{mg} / \mathrm{kg})$ at postnatal days 2 (P2) to $\mathrm{P} 5$ and perfused with ice-cold dissection solution consisting of (in mM) 250 sucrose, $2.5 \mathrm{KCl}, 25 \mathrm{NaHCO}_{3}, 1.0 \mathrm{NaH}_{2} \mathrm{PO}_{4}, 6 \mathrm{MgCl}_{2}$, $0.5 \mathrm{CaCl}_{2}$, and 25 glucose, continuously bubbled with $95 \% \mathrm{O}_{2} / 5 \% \mathrm{CO}_{2}$. The lumbar spinal cord (L2-L6) was isolated and immersed in lowmelting-point agarose ( $3 \%$ in the above solution; Invitrogen), and parasagittal slices $(350-400 \mu \mathrm{m})$ were cut using a Vibroslice tissue slicer (HA-752; Campden Instruments). The slices were placed in a chamber filled with oxygenated dissection solution for $30 \mathrm{~min}$ and allowed to recover in an oxygenated artificial CSF (aCSF) solution containing (in mм) $125 \mathrm{NaCl}, 2.5 \mathrm{KCl}, 25 \mathrm{NaHCO}_{3}, 1.0 \mathrm{NaH}_{2} \mathrm{PO}_{4}, 1.0 \mathrm{MgCl}_{2}, 2.0$ $\mathrm{CaCl}_{2}$, and 25 glucose, $\mathrm{pH} 7.2$, for $\geq 1 \mathrm{~h}$ at room temperature.

Patch-clamp recordings. After recovery, slices were transferred to a submersion-type recording chamber (RC-22; Warner Instruments) and mounted on the stage of an upright microscope (BX51WI; Olympus). Slices were then perfused at room temperature with oxygenated aCSF at a rate of $1.5-3 \mathrm{ml} / \mathrm{min}$.

Patch electrodes were constructed from thin-walled, single-filamented borosilicate glass ( $1.5 \mathrm{~mm}$ outer diameter; World Precision Instruments) using a microelectrode puller (P-97; Sutter Instruments). Pipette resistances ranged from 4 to $6 \mathrm{M} \Omega$, and seal resistances were $>1 \mathrm{G} \Omega$. In the majority of experiments, patch electrodes were filled with a solution containing the following (in $\mathrm{mm}$ ): $130 \mathrm{~K}$-gluconate, $10 \mathrm{KCl}, 10 \mathrm{HEPES}$, 10 Na-phosphocreatine, $4 \mathrm{MgATP}$, and $0.3 \mathrm{Na}_{2}$-GTP, pH 7.2 (305 mOsm). To determine the extent to which bursting activity within lamina I depended on the intracellular levels of free $\mathrm{Mg}^{2+}$, some experiments used either a "high- $\mathrm{Mg}^{2+}$ " internal solution [consisting of (in $\mathrm{mM}$ ) 130 K-gluconate, $10 \mathrm{KCl}, 10 \mathrm{HEPES}, 10 \mathrm{Na}$-phosphocreatine, $0.3 \mathrm{Na}_{2}$-GTP, $1.45 \mathrm{~K}_{2} \mathrm{ATP}$, and $2.55 \mathrm{MgCl}_{2}$ ] or a "low- $\mathrm{Mg}^{2+}$ " solution [composed of (in $\mathrm{mM}$ ) $90 \mathrm{~K}$-gluconate, $10 \mathrm{KCl}, 10 \mathrm{HEPES}, 10 \mathrm{Na}$-phosphocreatine, 0.3 $\mathrm{Na}_{2}$-GTP, $21.6 \mathrm{~K}_{2} \mathrm{ATP}$, and $1.56 \mathrm{MgCl}_{2}$ ]. Using a Mg-ATP calculator (version 1.3; MaxChelator) (Schoenmakers et al., 1992), the solutions were designed to produce free $\left[\mathrm{Mg}^{2+}\right]_{\text {internal }}$ of $1 \mathrm{~mm}\left(\right.$ high $\mathrm{Mg}^{2+}$ ) or 10 $\mu \mathrm{M}\left(\right.$ low $\left.\mathrm{Mg}^{2+}\right)$, while maintaining a constant $[\mathrm{Mg}-\mathrm{ATP}]_{\text {internal }}$ of 1.55 $\mathrm{mm}$ to minimize potential differences in ion channel phosphorylation and "rundown" between intracellular solutions (Pearson and Dolphin, 1993).

Dorsal horn neurons were visualized with infrared differential interference contrast, and patch-clamp recordings were obtained from L4-L5 cells located across the mediolateral extent of the spinal cord using a Multiclamp 700B amplifier (Molecular Devices). Sampled cells were categorized as lamina I neurons if they resided within $40 \mu \mathrm{m}$ of the edge of the dorsal white matter (Lorenzo et al., 2008). Approximately $1 \mathrm{~min}$ after establishment of the whole-cell configuration, the spontaneous firing patterns of dorsal horn neurons were classified at the resting membrane potential $\left(V_{\text {rest }}\right)$ as "silent," "irregular," "tonic," or "bursting" ( $\mathrm{Li}$ and Baccei, 2011). Membrane resistance $\left(R_{\mathrm{m}}\right)$ was measured using the hyperpolarization produced by negative current injections (5-10 pA) from $V_{\text {rest }}$.

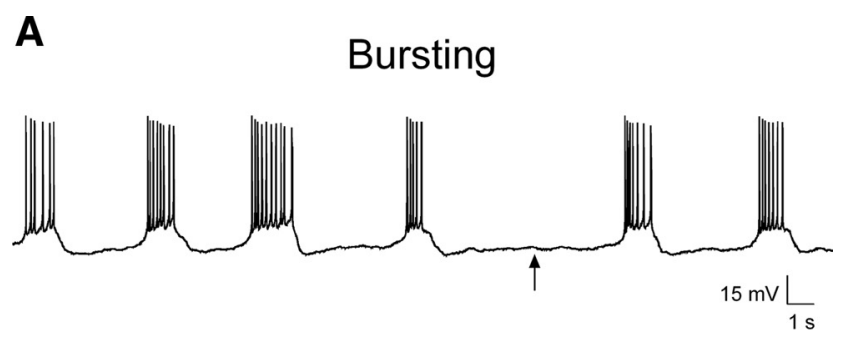

Tonic
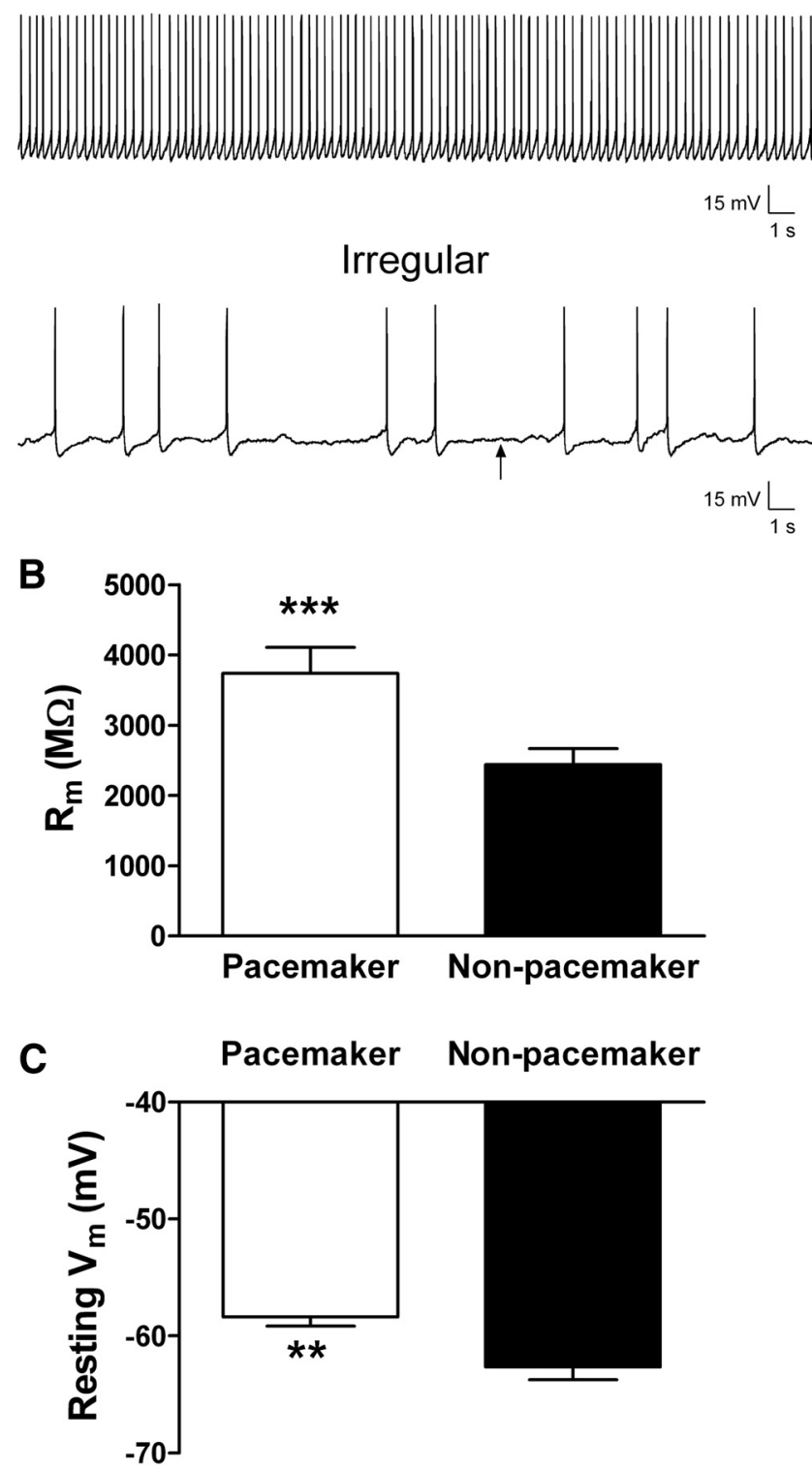

Figure 1. Lamina I pacemaker neurons are distinguished by high membrane resistance and depolarized resting potentials. $\boldsymbol{A}$, Spontaneous firing patterns were classified as rhythmic bursting (top), tonic (middle), irregular (bottom), or silent (data not shown). Arrows indicate approximate regions used to measure the resting membrane potential in a spontaneously active neuron. $\boldsymbol{B}$, Membrane resistance $\left(R_{\mathrm{m}}\right)$ was significantly higher in the pacemaker population of lamina I neurons compared with adjacent nonbursting neurons $\left({ }^{* * *} p=0.0001\right.$, Mann-Whitney test). $C$, Pacemaker neurons also exhibited a significantly more depolarized resting potential $(n=15)$ compared with nonpacemaker neurons $\left(n=22 ;{ }^{* *} p=0.007\right.$, Mann-Whitney test). Tonically firing neurons were excluded from the analysis because of difficulties in accurately measuring their resting potential. 
Non-pacemaker

A

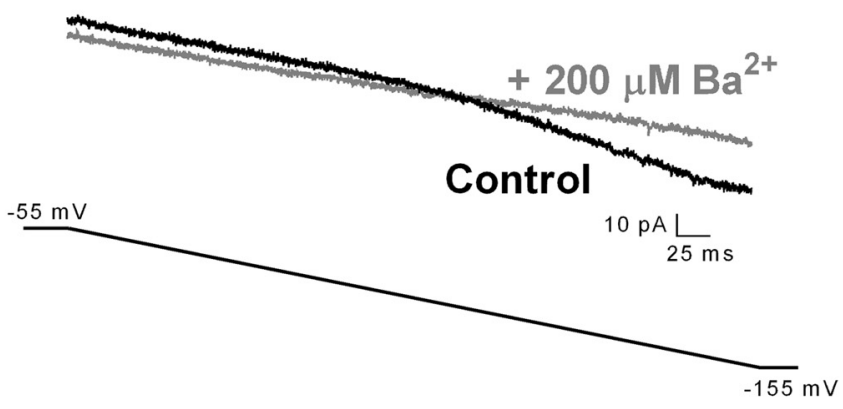

C

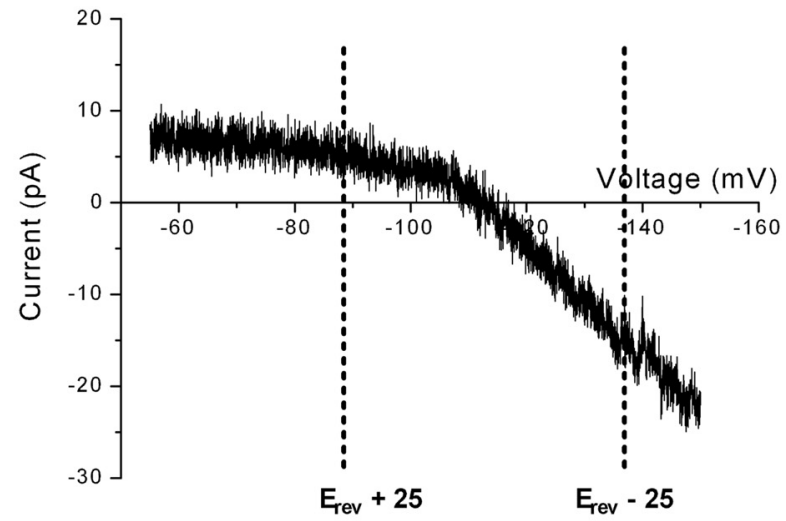

Pacemaker

B

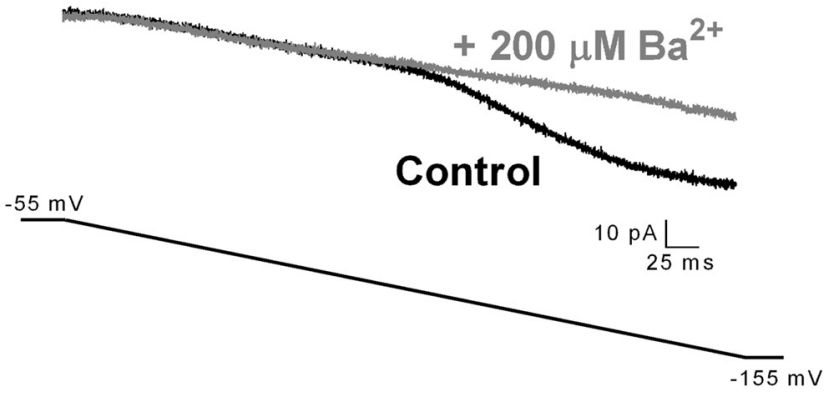

D

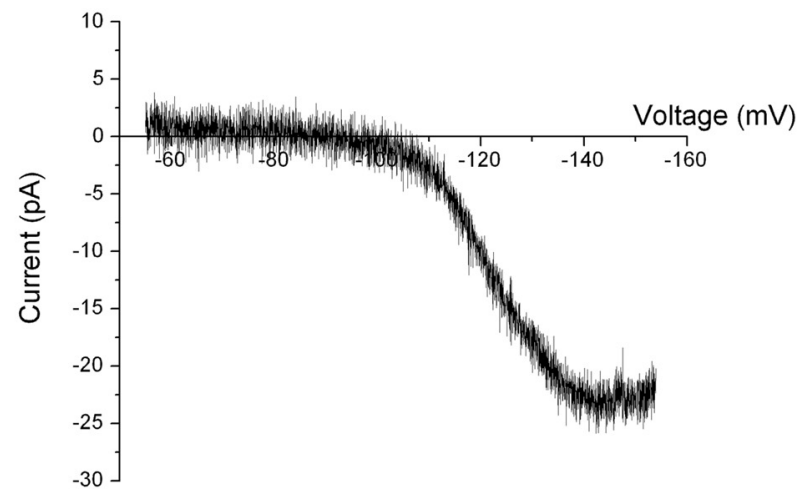

E

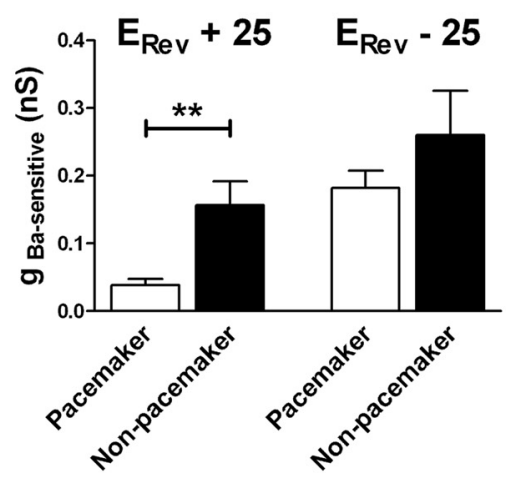

F

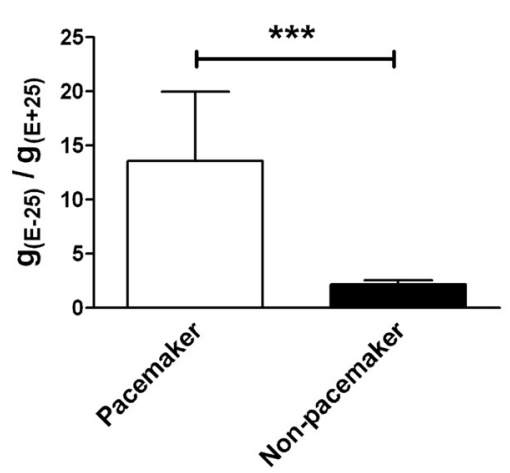

G

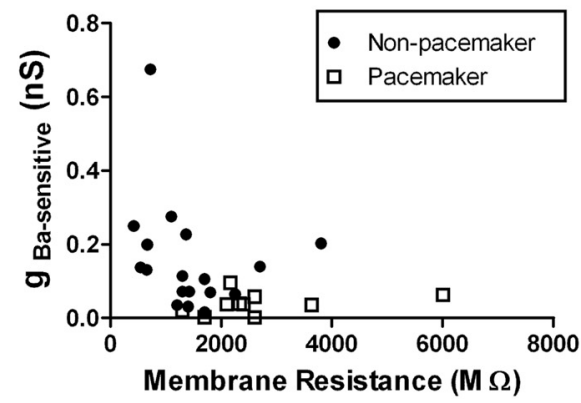

Figure 2. Low $\mathrm{K}_{\mathrm{ir}}$ conductance in spontaneously bursting neurons within the newborn SDH. $A$, Representative currents recorded in nonpacemaker neurons during negative voltage ramps from a holding potential of -55 to $-155 \mathrm{mV}$ before (control; black) and after (gray) the bath application of $200 \mu \mathrm{M} \mathrm{BaCl}$. The illustrated example corresponds to a silent lamina I neuron at P3. $\boldsymbol{B}$, Representative traces obtained using the same protocol as in $A$, administered to a lamina I pacemaker neuron. Note the overlap in traces during the early portion of the negative voltage ramp. $C, D$, Example of $\mathrm{Ba}^{2+}$-sensitive currents obtained by electronic subtraction (black minus gray) plotted as a function of membrane voltage for nonpacemaker $(\boldsymbol{C})$ and pacemaker $(\boldsymbol{D})$ neurons within lamina I of the neonatal spinal cord. Inward rectification was observed in all cases as the slope was greater at potentials negative to the observed reversal potential $\left(E_{\text {rev }}\right)$. Cincludes representative voltages (equidistant from $E_{\text {rev }}$ ) used to calculate the Ba ${ }^{2+}$-sensitive conductance $\left(g_{\text {Ba-sensitive }}\right.$ ). $\boldsymbol{E}$, Bursting lamina I neurons possessed significantly lower $g_{\text {Ba-sensitive }}$ compared with adjacent nonbursting cells at potentials positive to $E_{\text {rev }}$ (** $p=0.002$, Mann-Whitney test; left) but not at potentials more negative than $E_{\text {rev }}(p=0.981$; right). $\boldsymbol{F}$, The degree of inward rectification of $\mathrm{Ba}^{2+}$-sensitive $\mathrm{K}^{+}$currents [measured as $g_{(\text {Erev -25) }} / g_{\text {(Erev }+25)}$ ] was significantly greater in the population of pacemaker neurons within lamina I $(* * * p=0.0007$, Mann-Whitney test). G, Across the general population of neonatal lamina I neurons, there was a significant inverse correlation between the level of $\mathrm{Ba}^{2+}$-sensitive conductance and the membrane resistance $(r=-0.398 ; p=$ 0.036 ; Spearman's test), suggesting an important contribution of $g_{\text {Ba-sensitive }}$ to resting leak conductance within these cells.

Inward-rectifying $\mathrm{K}^{+}\left(\mathrm{K}_{\mathrm{ir}}\right)$ currents were isolated as described previously (Derjean et al., 2003). Briefly, neurons were voltage clamped at -55 $\mathrm{mV}$ in the presence of $10 \mu \mathrm{M}$ NBQX, $25 \mu \mathrm{M}$ AP-5, $10 \mu \mathrm{M}$ gabazine, and 0.5 $\mu \mathrm{M}$ strychnine to block fast synaptic transmission in the slice. Negative voltage ramps (from -55 to $-155 \mathrm{mV}$ ) were applied at a rate of 0.2
$\mathrm{mV} / \mathrm{ms} . \mathrm{BaCl}_{2}(0.2-200 \mu \mathrm{M})$ was bath applied to block $\mathrm{K}_{\mathrm{ir}}$ (Coetzee et al., 1999), and the $\mathrm{Ba}^{2+}$-sensitive component of the current was subsequently isolated via electronic subtraction (see Fig. 2). Conductance ( $\left.g_{\text {Ba-sensitive }}\right)$ was calculated as $g=I /\left(V_{\mathrm{m}}-E_{\text {rev }}\right)$, at two different membrane potentials that were equidistant $(25 \mathrm{mV})$ from the reversal poten- 
tial (Derjean et al., 2003). To estimate the degree of $\mathrm{K}_{\mathrm{ir}}$ inward rectification, a ratio of these two conductances was calculated as follows: $g_{(\mathrm{E}-25)} / g_{(\mathrm{E}+25)}$. The potential contribution of constitutively active G-protein-coupled $\mathrm{K}_{\mathrm{ir}}$ channels (GIRKs) to the above ramp currents was investigated by bath-applying the selective GIRK antagonist tertiapin-Q $(100 \mathrm{~nm})$. Bovine serum albumin $(0.1 \mathrm{mg} / \mathrm{ml})$ was included in the solution to reduce nonspecific binding of the peptide to the perfusion tubing. At this concentration, tertiapin-Q was found to partially block the outward currents evoked by the $\mathrm{GABA}_{\mathrm{B}}$ receptor $\left(\mathrm{GABA}_{\mathrm{B}} \mathrm{R}\right)$ agonist baclofen (data not shown), confirming that the peptide adequately penetrated the slice under our experimental conditions. To examine the expression of hyperpolarization-activated cation currents $\left(I_{\mathrm{h}}\right)$ in lamina I neurons, hyperpolarizing voltage steps (from -70 to $-150 \mathrm{mV}$ in 10 $\mathrm{mV}$ increments) were delivered from a holding potential of $-60 \mathrm{mV}$. Alternatively, in current-clamp mode, hyperpolarizing current steps $(0-20 \mathrm{pA})$ were administered from the resting potential to detect the presence of a depolarizing "sag" in the membrane potential region, which is characteristic of $I_{\mathrm{h}}$ expression (Yoshimura and Jessell, 1989).

Membrane voltages were adjusted for liquid junction potentials $(\sim 14$ $\mathrm{mV}$ ) calculated using JPCalc software (P. Barry, University of New South Wales, Sydney, Australia; modified for Molecular Devices) unless otherwise specified. Currents were filtered at $4-6 \mathrm{kHz}$ through a $-3 \mathrm{~dB}$, four-pole low-pass Bessel filter; digitally sampled at $20 \mathrm{kHz}$; and stored on a personal computer (ICT) using a commercially available data acquisition system (Digidata 1440A with pClamp 10.2 software; Molecular Devices).

Biocytin staining and immunohistochemistry. Rat pups (P1-P5) of either sex were deeply anesthetized with sodium pentobarbital $(30 \mathrm{mg} / \mathrm{kg}$, i.p.), perfused with aCSF solution, and decapitated. The lumbar spinal cord was isolated with dura and pia matter removed from the dorsal surface. The intact cord was transferred to the recording chamber and perfused at room temperature with oxygenated aCSF at $1.5-3 \mathrm{ml} / \mathrm{min}$. Whole-cell patch-clamp recordings were obtained from lamina I neurons under infrared LED illumination (Safronov et al., 2007; Szucs et al., 2009) using the standard K-gluconate intracellular solution (see above) with the addition of $0.3 \%$ biocytin. Following the classification of spontaneous firing pattern (Fig. 1), nonbursting neurons were removed from the spinal cord under visual control via strong negative pressure applied to the electrode, thus ensuring that cells later identified with biocytin staining corresponded to pacemakers. Meanwhile, neurons exhibiting spontaneous burst firing were dialyzed with biocytin for 30-40 min. Approximately two to six pacemaker neurons were labeled in this manner per spinal cord.

The spinal cords were then fixed overnight at $4^{\circ} \mathrm{C}$ in $4 \%$ paraformaldehyde, followed by cryoprotection in 30\% sucrose in $0.1 \mathrm{M}$ PBS overnight. Cords were rapidly frozen, and parasagittal sections were cut at 10 $\mu \mathrm{m}$ on a cryostat, mounted onto Superfrost Plus slides (Fisher Scientific), and left to dry overnight on a slide warmer at $39^{\circ} \mathrm{C}$. Sections were washed three times for $5 \mathrm{~min}$ in $0.1 \mathrm{M}$ PBS, permeabilized with $0.3 \%$ Tween 20 in $0.1 \mathrm{M}$ PBS for $10 \mathrm{~min}$, and incubated with avidin conjugated to Rhodamine Red (1:1000; Invitrogen) for $2 \mathrm{~h}$ at room temperature. The slides were then washed an additional three times for $5 \mathrm{~min}$ in $0.1 \mathrm{M}$ PBS and loosely coverslipped with an excess of Vectashield mounting medium (Vector Laboratories), and biocytin-filled neurons were visualized on a Microshot-SA fluorescence microscope (Nikon). Slides containing labeled neurons were then subjected to immunostaining for $\mathrm{K}_{\mathrm{ir}} 2$ channels as described below.

Slides containing labeled cells (or those selected for peptide preabsorption control experiments) were additionally washed six times for $10 \mathrm{~min}$ and blocked in $10 \%$ normal goat serum/0.3\% Tween 20 in 0.1 м PBS for $1 \mathrm{~h}$. Primary antibodies raised in rabbit against $\mathrm{K}_{\mathrm{ir}} 2.1$ or $\mathrm{K}_{\mathrm{ir}} 2.3$ (1:200; Alomone Labs) or $\mathrm{K}_{\mathrm{ir}} 2.2$ (1:250; Epitomics) were applied in dilution buffer containing $2 \%$ normal goat serum, $0.06 \%$ Tween 20 , and $0.1 \mathrm{M}$ $\mathrm{PBS}$ and incubated for $48 \mathrm{~h}$ at $4^{\circ} \mathrm{C}$. For each antibody used, a preabsorption control was prepared by incubating an undiluted antibody with its corresponding peptide (Alomone Labs) in a 1:5 to 1:10 ratio for $1 \mathrm{~h}$ before antibody dilution. Tissue was then washed three times for $5 \mathrm{~min}$ in $0.3 \%$ Tween 20 in $0.1 \mathrm{M}$ PBS and incubated for $2 \mathrm{~h}$ at room temperature in a goat anti-rabbit secondary antibody conjugated to Alexa 488 (1:

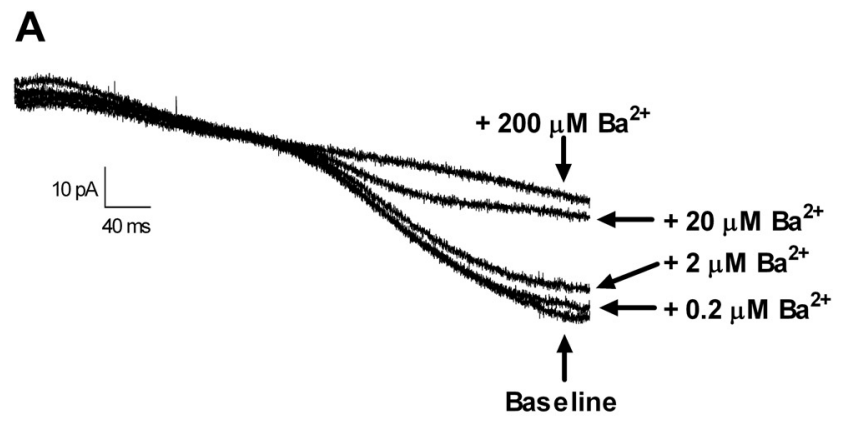

B
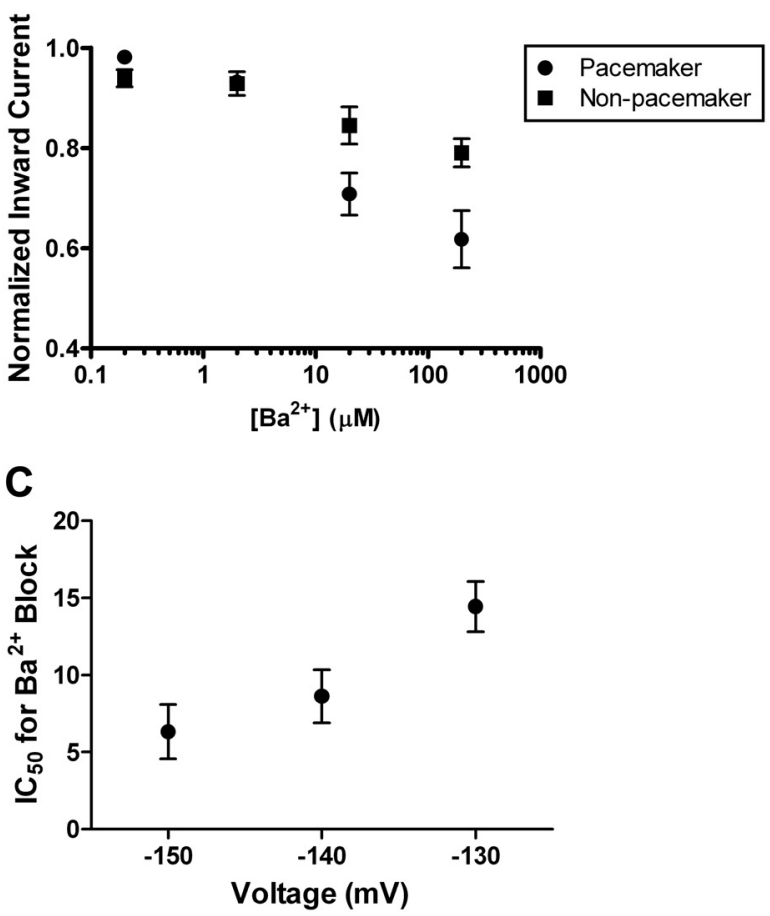

Figure 3. High $\mathrm{Ba}^{2+}$ sensitivity of $\mathrm{K}_{\mathrm{ir}}$ currents in neonatal lamina I neurons. $\boldsymbol{A}$, Representative currents evoked during voltage ramps from -55 to $-155 \mathrm{mV}$ in an individual lamina I pacemaker neuron at baseline and in the presence of increasing concentrations of external $\mathrm{BaCl}_{2}$ $(0.2-200 \mu \mathrm{M}) . B$, Dose-response relationships suggest that a fraction of the recorded current (measured at $-140 \mathrm{mV}$ ) was highly sensitive to $\mathrm{Ba}^{2+}$ block in both pacemaker and nonpacemaker populations within lamina I of the immature spinal cord. $C$, The measured $I_{50}$ for the block by external $\mathrm{Ba}^{2+}$ was voltage dependent, consistent with the presence of classical $\mathrm{K}_{\mathrm{ir}} 2 . \mathrm{x}$ channels. Data are pooled from bursting and nonbursting groups of lamina I cells.

1000 ) diluted in $2 \%$ normal goat serum in $0.1 \mathrm{~m}$ PBS. Sections were washed six times for $5 \mathrm{~min}$ and coverslipped with Vectashield. Images were acquired on a LSM510 inverted confocal microscope (Zeiss) with a $63 \times$ Real Zoom oil-immersion objective and processed in Zen imaging software. Cells were imaged at an optical thickness of $0.5 \mu \mathrm{m}$ to visualize the presence of $K_{i r}$ protein located on the cell surface. Cells were determined to express $\mathrm{K}_{\mathrm{ir}} 2.1, \mathrm{~K}_{\mathrm{ir}} 2.2$, or $\mathrm{K}_{\mathrm{ir}} 2.3$ protein if Alexa 488-positive puncta colocalized with avidin-conjugated rhodamine fluorescence.

Data analysis and statistics. Electrophysiological data were analyzed using Clampfit (Molecular Devices) and Origin (OriginLab Corporation) software. Neurons were classified as bursting (i.e., pacemakers) if they exhibited slow oscillations in membrane potential that gave rise to multiple action potentials ( $\mathrm{Li}$ and Baccei, 2011). Nonparametric tests were used in cases in which the distribution of data failed the D'Agostino \& Pearson normality test (Prism; GraphPad Software) or when the number of observations was insufficient $(n<24)$ to definitively conclude that data were distributed in a Gaussian manner. $p<0.05$ was considered 
significant. $n$ refers to the number of neurons sampled in a given group. Data are expressed as means \pm SEM.

\section{Results}

Pacemaker neurons are distinguished by low conductance through $\mathrm{Ba}^{2+}$ sensitive $K_{\mathrm{ir}}$ channels

To identify which subtypes of leak conductance are important for regulating pacemaker activity in the newborn superficial dorsal horn, we obtained in vitro whole-cell patch-clamp recordings from lamina I neurons in rat spinal cord slices prepared at P2-P5. The pattern of spontaneous activity at room temperature was classified as bursting, tonic, irregular (Fig. $1 A$ ) or silent (data not shown), as described previously (Li and Baccei, 2011). The observed rhythmic burst firing was previously shown to reflect the intrinsic membrane properties of the lamina I neuron, thus constituting "pacemaker" activity within the superficial dorsal horn ( $\mathrm{Li}$ and Baccei, 2011). Pacemaker neurons exhibited a significantly higher membrane resistance (i.e., lower resting leak conductance) compared with adjacent nonbursting lamina I neurons $(n=33-40$ in each group; $p=0.0001$, Mann-Whitney test; Fig. $1 B)$. This was accompanied by a significantly more depolarized resting potential $\left(V_{\text {rest }}\right)$ within the pacemaker population ( $p=0.007$, Mann-Whitney test; Fig. 1C). Since membrane resistance in SDH neurons decreases with elevated temperature (Graham et al., 2008), we obtained additional recordings from neonatal lamina I neurons at $32-34^{\circ} \mathrm{C}$ and found that 9 of the 20 neurons sampled (45\%) exhibited spontaneous pacemaker activity. Critically, this demonstrates that the intrinsic burst firing is not an artifact related to recording at room temperature.

$\mathrm{K}_{\mathrm{ir}}$ channels are known to be important for the maintenance of $V_{\text {rest }}$ in both neurons and muscle through their contribution to the leak membrane conductance (Hibino et al., 2010). Therefore, we hypothesized that the distinct passive membrane properties (Fig. $1 B, C$ ) of pacemaker neurons reflect, at least in part, a reduced $\mathrm{K}_{\mathrm{ir}}$ conductance near the resting potential. After the classification of the spontaneous firing pattern, voltage-clamp experiments were performed in which lamina I neurons were hyperpolarized from -55 to $-155 \mathrm{mV}$ (at a rate of $0.2 \mathrm{mV} / \mathrm{ms}$ ) in the presence of a mixture of antagonists to block fast synaptic transmission in the slice (see Materials and Methods). $\mathrm{BaCl}_{2}$ (200 $\mu \mathrm{M})$ was subsequently added to the bath. Electronic subtraction of the $\mathrm{Ba}^{2+}$-sensitive component revealed a current with a mean reversal potential $\left(E_{\text {rev }}\right)$ of $-97.7 \pm 2.5 \mathrm{mV}(n=28)$, which was close to the predicted equilibrium potential for $\mathrm{K}^{+}$ions under our experimental conditions $(-101.4 \mathrm{mV})$. Measurements of conductance (see Materials and Methods) at two potentials equidistant from $E_{\text {rev }}$ (Fig. 2C) (Derjean et al., 2003) consistently demonstrated inward rectification, as evidenced by a higher conductance at more negative membrane potentials $\left(V_{\mathrm{m}}\right)$, which is consistent with the isolation of $\mathrm{K}_{\mathrm{ir}}$ current using this protocol.
The effects of extracellular $\mathrm{Ba}^{2+}$ application on the current evoked by the negative voltage ramp clearly differed between pacemaker and nonpacemaker neurons within lamina I of the neonatal spinal cord. In nonpacemakers, $\mathrm{Ba}^{2+}$ blocked a portion of the recorded current throughout the voltage ramp, thus lowering the overall slope of the observed current (Fig. $2 A, C$ ). Meanwhile, in pacemaker neurons from the same slices, $\mathrm{Ba}^{2+}$ evoked only a minimal block of the current between -55 and $-85 \mathrm{mV}$ (Fig. 2B,D), suggesting a reduced $\mathrm{K}_{\mathrm{ir}}$ conductance in this population at these physiological membrane potentials. Indeed, the conductance of the $\mathrm{Ba}^{2+}$-sensitive component $\left(g_{\text {Ba-sensitive }}\right)$ was significantly lower in the bursting group $(0.039 \pm 0.009 \mathrm{nS} ; n=10)$ compared with nonbursting lamina I neurons $(0.156 \pm 0.036 \mathrm{nS} ; n=18 ; p=0.002$, Mann-Whitney test; Fig. $2 E$, left) at $V_{\mathrm{m}}$ positive to the reversal potential (i.e., $\left.E_{\text {rev }}+25\right)$. However, the level of $g_{\text {Ba-sensitive was not }}$ statistically different between groups when measured at more negative potentials (i.e., $E_{\mathrm{rev}}-25 ; p=0.981$; Fig. $2 E$, right). As a result, $\mathrm{K}_{\mathrm{ir}}$ currents exhibited a greater degree of inward rectification within the pacemaker population, as the ratio of $g_{\text {Ва-sensitive }}$ measured at the more negative $V_{\mathrm{m}}$ relative to that measured at the positive $V_{\mathrm{m}}$ was significantly elevated in the bursting neurons ( $p=0.0007$, MannWhitney; Fig. $2 F)$. These data indicate that the lower $g_{\text {Ba-sensitive }}$ that characterizes pacemakers at physiological membrane potentials cannot be simply explained by a lower number of $\mathrm{K}_{\mathrm{ir}}$ channels and in turn suggests that bursting neurons express distinct $\mathrm{K}_{\mathrm{ir}}$ currents compared with adjacent nonbursting neurons within lamina I of the neonatal spinal cord. 

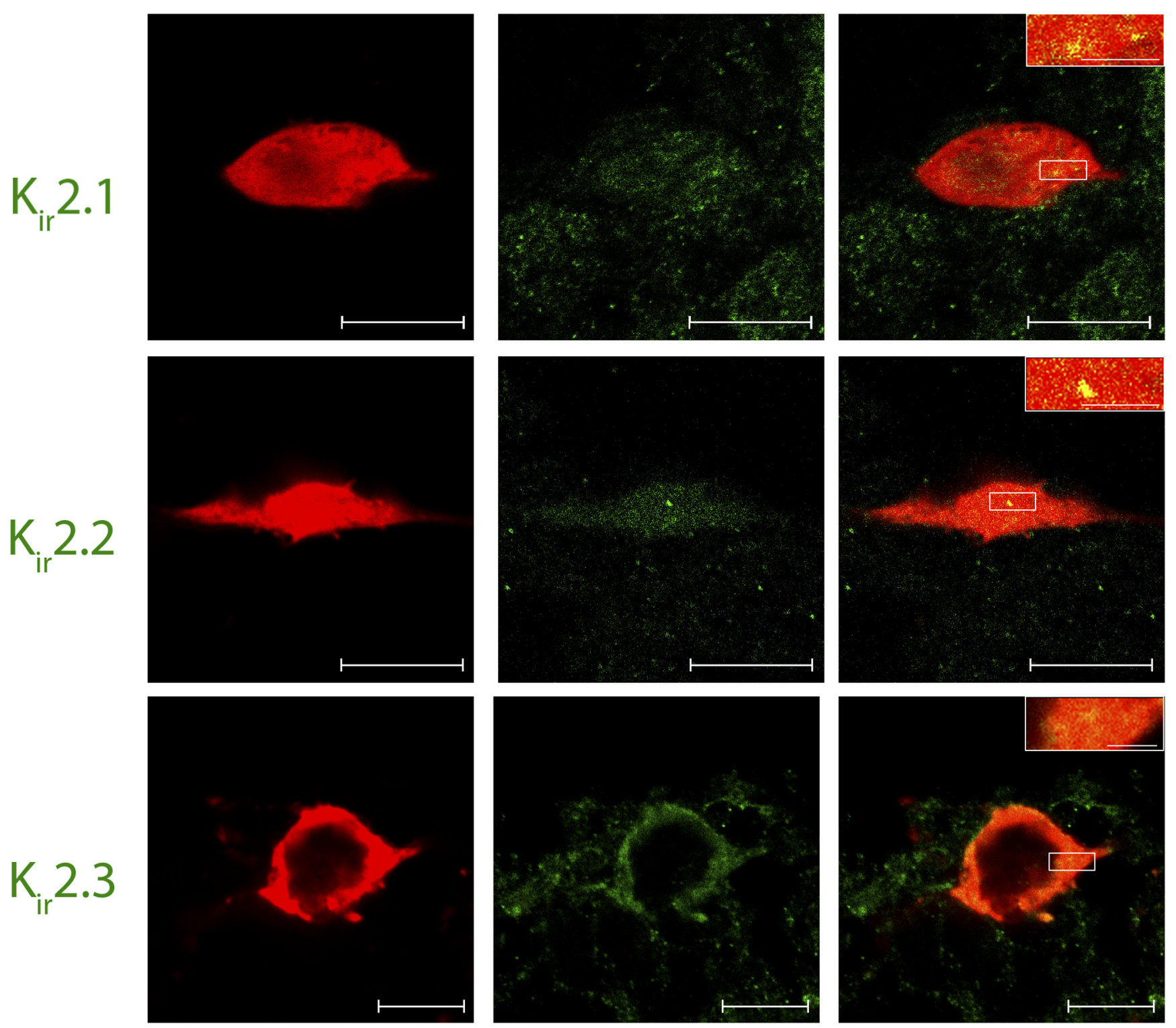

Figure 5. Lamina I pacemaker neurons express classical $K_{\text {ir }} 2.1-2.3$ channels. Confocal images ( $0.5 \mu$ m optical thickness) of representative biocytin-filled pacemaker neurons (red) processed for $\mathrm{K}_{\mathrm{ir}}$ immunohistochemistry (green) with $\mathrm{K}_{\mathrm{ir}} 2.1$ (top row), $\mathrm{K}_{\mathrm{ir}} 2.2$ (middle row), or $\mathrm{K}_{\mathrm{ir}} 2.3$ (bottom row) antibodies. Merged images demonstrate that immunoreactive puncta for all three $\mathrm{K}_{\mathrm{ir}} 2$ isoforms (yellow; inset) were localized to identified pacemaker neurons within lamina I of the neonatal spinal cord (right). Scale bars: $10 \mu \mathrm{m}$; inset, $2 \mu \mathrm{m}$.

Importantly, $g_{\text {Ba-sensitive }}$ measured at positive membrane potentials (i.e., $\left.E_{\text {rev }}+25\right)$ was inversely correlated with membrane resistance $\left(R_{\mathrm{m}}\right)$ across the lamina I population $(r=$ $-0.398 ; n=28 ; p=0.036$; Spearman's test; Fig. $2 G)$. This supports the notion that $\mathrm{Ba}^{2+}$-sensitive leak conductance is an important determinant of $R_{\mathrm{m}}$ in the developing superficial dorsal horn.

\section{Bursting lamina I neurons express classical $\mathrm{K}_{\mathrm{ir}}$ channels during early life}

Classical $\mathrm{K}_{\mathrm{ir}}$ channels $\left(\mathrm{K}_{\mathrm{ir}} 2 . \mathrm{x}\right)$ are known to be constitutively active near the resting potential, exhibit strong inward rectification, and are highly sensitive to block by external $\mathrm{Ba}^{2+}$ (Hibino et al., 2010). However, it remains unclear whether functional $\mathrm{K}_{\mathrm{ir}} 2$.x channels are expressed within the developing dorsal horn. To better characterize the $\mathrm{K}_{\mathrm{ir}}$ channels found in neonatal lamina I neurons, we examined the sensitivity of $\mathrm{K}_{\mathrm{ir}}$ currents to increasing concentrations of extracellular $\mathrm{Ba}^{2+}$ (Fig. $3 A$ ). In both pace- maker and nonpacemaker populations within lamina I, the currents evoked by the negative voltage ramp were highly sensitive to external $\mathrm{Ba}^{2+}\left(\mathrm{IC}_{50}\right.$ at $V_{\mathrm{m}}=-140 \mathrm{mV}$; bursting: $8.62 \pm 1.7 \mu \mathrm{M}$, $n=6$; nonbursting: $13.9 \pm 2.3 \mu \mathrm{M}, n=8 ; p=0.109$, unpaired $t$ test; Fig. $3 B$ ). In addition, the sensitivity to $\mathrm{Ba}^{2+}$ block was lower at more depolarized potentials (Fig. 3C), which is consistent with the known properties of classical $\mathrm{K}_{\mathrm{ir}} 2$.x channels (Liu et al., 2001; Young et al., 2009).

However, it should be noted that GIRK channels $\left(\mathrm{K}_{\mathrm{ir}} 3 . \mathrm{x}\right)$ also exhibit strong inward rectification and sensitivity to external $\mathrm{Ba}^{2+}$ (Coetzee et al., 1999). GIRK channels can be constitutively active within some types of central neurons (Takigawa and Alzheimer, 2002; Chen and Johnston, 2005) and thus modulate their resting leak conductance. Importantly, we observed no evidence of tonic GIRK channel activity in neonatal lamina I neurons regardless of the pattern of spontaneous activity, as leak conductance in both bursting $(n=6$; Fig. $4 A, B)$ and nonbursting $(n=4)$ cells was unaffected by the bath application of the selec- 
tive GIRK antagonist tertiapin-Q (Jin and $\mathrm{Lu}$, 1998). This strongly suggests that GIRK channels do not contribute to resting leak conductance within the immature $\mathrm{SDH}$ and therefore are not responsible for the $\mathrm{Ba}^{2+}$-sensitive $\mathrm{K}^{+}$ currents isolated in our experiments (Fig. 2).

Alternatively, the strong inward rectification observed in pacemaker neurons during the negative voltage ramp (Fig. $2 D$ ) could potentially reflect the onset of hyperpolarization-activated cation currents $\left(I_{\mathrm{h}}\right)$, which have been documented in the rodent superficial dorsal horn (Grudt and Perl, 2002). However, this seems unlikely given the high sensitivity of the observed currents to external $\mathrm{Ba}^{2+}$ (Fig. $3 A, B$ ), since $I_{\mathrm{h}}$ is reported to be insensitive to $\mathrm{Ba}^{2+}$ at submillimolar concentrations (Robinson and Siegelbaum, 2003). Nonetheless, to further address this issue, voltage-clamp and current-clamp protocols were used to detect the presence of $I_{\mathrm{h}}$ in identified pacemaker neurons within lamina I during early life (see Materials and Methods). In 12 of 13 pacemaker neurons examined, negative voltage steps between -70 and $-150 \mathrm{mV}$ failed to evoke a slowly activating inward current (Fig. 4C). In addition, injections of hyperpolarizing current into bursting neurons did not produce the depolarizing sag in the membrane potential that is characteristic of $I_{\mathrm{h}}$ expression (Fig. 4D). Similarly, the vast majority of nonbursting neurons ( 59 of $63 ; p=1.0$ compared with bursting cells, Fisher's exact test) also failed to show evidence of $I_{\mathrm{h}}$ expression (Fig. $4 E$ ), suggesting that $I_{\mathrm{h}}$ is not an important contributor to leak conductance in lamina I during early life. Overall, these results further support the idea that the strongly rectifying, highly $\mathrm{Ba}^{2+}$-sensitive currents in newborn lamina I cells correspond to $\mathrm{K}^{+}$flux through $\mathrm{K}_{\mathrm{ir}} 2$.x channels.

The low $\mathrm{K}_{\mathrm{ir}}$ conductance that distinguishes spinal pacemakers (Fig. 2) could reflect the absence of particular $\mathrm{K}_{\mathrm{ir}} 2 . \mathrm{x}$ isoforms within this population. To investigate this possibility, we characterized the pattern of $\mathrm{K}_{\mathrm{ir}} 2$.x expression within identified pacemaker neurons using immunohistochemistry. Wholecell patch-clamp recordings (with biocytin included in the intracellular solution) were obtained from bursting lamina I neurons in an intact spinal cord preparation (Safronov et al., 2007; Szucs et al., 2009), which has the advantages of better preserving anatomical structures within the dorsal horn and facilitating tissue sectioning for subsequent immunohistological analysis of the recorded neuron. The results clearly indicate that the population of lamina I pacemaker neurons expresses multiple subtypes of classical $\mathrm{K}_{\mathrm{ir}} 2$.x channels. $\mathrm{K}_{\mathrm{ir}} 2.1$ immunoreactivity was observed in every lamina I neuron exhibiting spontaneous, rhythmic burst firing (13 of 13 cells examined; Fig. 5, top). Similarly, $\mathrm{K}_{\mathrm{ir}} 2.2-$ positive puncta were found in nine of nine pacemaker cells sampled (Fig. 5, middle). Finally, the vast majority of bursting neurons (10 of 12) also demonstrated immunoreactivity for $\mathrm{K}_{\mathrm{ir}} 2.3$ (Fig. 5, bottom). In all cases, preabsorption of the $\mathrm{K}_{\mathrm{ir}} 2$ primary antibody with the relevant antigen, or omission of the primary antibody, failed to produce measurable signals within the SDH (data not shown). Collectively, the data suggest that $\mathrm{K}_{\mathrm{ir}}$ 2.x channels are well positioned to regulate the firing of lamina I neurons within the newborn spinal cord.

\section{Block of $\mathrm{K}_{\mathrm{ir}}$ channels unmasks rhythmic burst firing in neonatal lamina I neurons}

The observation that lamina I pacemaker neurons are distinguished by their high membrane resistance (Fig. $1 B$ ) and reduced $g_{\text {Ba-sensitive }}$ near the resting membrane potential (Fig. $2 E$ ) suggests $\mathrm{K}_{\mathrm{ir}}$ channels modulate the generation of pacemaker activity within the developing SDH. To further examine this possibility, $\mathrm{BaCl}_{2}$ was bath applied (10 $\mu \mathrm{M}$ to $\left.1 \mathrm{mM}\right)$ to nonbursting neurons within lamina I of the neonatal spinal cord. External $\mathrm{Ba}^{2+}$ evoked a depolarizing shift in membrane potential in these cells (3.04 \pm $0.73 \mathrm{mV} ; n=33$ ). More importantly, in a significant proportion of neurons that initially showed either a tonic ( 3 of 7 cells examined) or irregular ( 5 of 14 cells) pattern of spontaneous activity, the administration of extracellular $\mathrm{Ba}^{2+}$ promoted a switch to rhythmic burst firing that was often reversible after washout (Fig. $6 A, C$ ). In addition, in 6 of the 12 silent lamina I neurons sampled, $\mathrm{Ba}^{2+}$ application evoked a slow membrane depolarization with subsequent generation of spontaneous bursting (Fig. $6 B$ ). In many cases, this burst firing could be silenced by the injections of small amounts $(\leq 2 \mathrm{pA})$ of hyperpolarizing current through the patch electrode (Fig. $6 B$ ), indicating that even minor shifts in $g_{\text {Ba-sensitive }}$ may have profound consequences for the pattern of spontaneous activity within this population. The recruitment of burst firing is unlikely to be solely explained by the depolarization produced by $\mathrm{Ba}^{2+}$, as our previous work demon- 
A

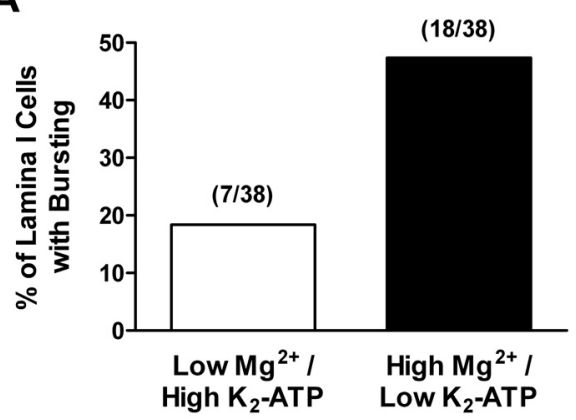

B

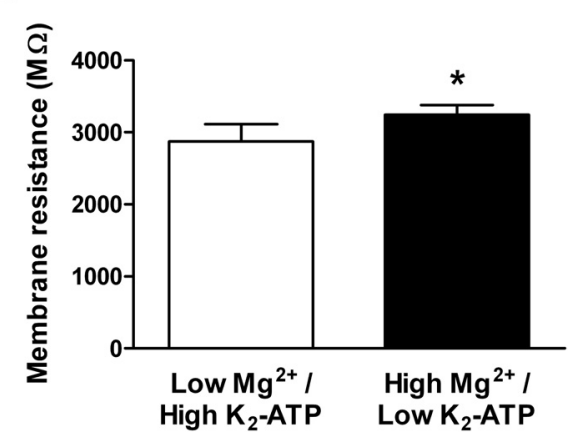

Figure 7. Prevalence of rhythmic burst firing is regulated by intracellular cation levels within neonatal lamina I neurons. $A$, Elevating the intracellular levels of free $\mathrm{Mg}^{2+}$ (to $\sim 1 \mathrm{~mm}$ ) significantly increased the percentage of lamina I neurons demonstrating pacemaker activity during early life ( $p=0.014$, Fisher's exact test). $\boldsymbol{B}$, Across the general population of lamina I neurons, a significantly greater membrane resistance was observed with the use of the high- $\mathrm{Mg}^{2+}$ intracellular solution $\left({ }^{*} p=0.013\right.$, Mann-Whitney test) compared with the use of a patch solution containing low internal $\mathrm{Mg}^{2+}$ within the same slices.

strated that directly depolarizing nonpacemaker neurons via the patch electrode only evoked bursting in $\sim 12 \%$ of cells at P2-P3 (Li and Baccei, 2011). Collectively, these results suggest that the propensity of a given lamina I neuron to generate pacemaker activity is tightly controlled by the level of leak conductance through $\mathrm{Ba}^{2+}$-sensitive $\mathrm{K}_{\mathrm{ir}}$ channels.

Strong inward rectification is not an innate property of $\mathrm{K}_{\mathrm{ir}}$ channels, but rather arises from the voltage-dependent block of the channel pore by intracellular free $\mathrm{Mg}^{2+}$ (Matsuda et al., 1987; $\mathrm{Lu}$ and MacKinnon, 1994) and internal free polyamines (Lopatin et al., 1994; Fakler et al., 1995). Therefore, if rhythmic bursting in lamina I neurons is indeed regulated by $\mathrm{K}_{\mathrm{ir}}$ channels, one would predict that the prevalence of pacemaker activity within the neonatal SDH could be significantly altered by manipulating the intracellular concentrations of these free cations. To further investigate this issue, whole-cell patch-clamp recordings from neonatal lamina I neurons were alternately obtained using intracellular recording solutions designed to contain either low $(\sim 10$ $\mu \mathrm{M})$ or high $(\sim 1 \mathrm{mM})$ levels of free $\mathrm{Mg}^{2+}$ via manipulations of the internal ATP concentration (see Materials and Methods). Although our intracellular recording solution did not contain polyamines, endogenous polyamines can be very slow to "wash out" during dialysis in the whole-cell configuration (Shin et al., 2005; Fleidervish et al., 2008). In addition, since ATP also strongly binds to polyamines (Watanabe et al., 1991), altering the internal levels of ATP in our sampled neurons will also modify the intracellular concentration of free polyamines, such that the high $\left[\mathrm{Mg}^{2+}\right]_{\text {free }}$ solution should also contain elevated levels of free polyamines. Importantly, a significantly higher percentage
(18 of 38; 47\%) of lamina I neurons exhibited rhythmic burst firing when the high $\left[\mathrm{Mg}^{2+}\right]_{\text {free }}$ internal solution was used, compared with neurons from the same spinal cord slices dialyzed with the low internal $\left[\mathrm{Mg}^{2+}\right]_{\text {free }}$ solution $(7$ of $38 ; 18 \% ; p=0.014$, Fisher's exact test; Fig. 7A). This was accompanied by a significantly higher membrane resistance under high $\left[\mathrm{Mg}^{2+}\right]_{\text {free }}$ conditions $(p=0.013$, Mann-Whitney test; Fig. $7 B)$. It should be noted that these experiments cannot conclusively determine whether the increased prevalence of bursting seen with the high$\mathrm{Mg}^{2+} /$ low-ATP internal solution was attributable to elevations in free $\mathrm{Mg}^{2+}$ or free polyamines, as the intracellular polyamine concentration remains unknown. Nonetheless, these data provide further support for the notion that $\mathrm{K}_{\mathrm{ir}}$ channels are key modulators of intrinsic burst firing within developing spinal nociceptive circuits.

\section{Discussion}

These results provide the first evidence that classical $\mathrm{K}_{\mathrm{ir}}$ channels serve as important regulators of pacemaker activity within the developing spinal cord. Neonatal lamina I neurons exhibiting spontaneous burst firing were characterized by higher membrane resistance $\left(R_{\mathrm{m}}\right)$ and more depolarized resting potentials $\left(V_{\text {rest }}\right)$ compared with adjacent nonbursting neurons, which was associated with a significantly lower $\mathrm{K}_{\mathrm{ir}}$ conductance near $V_{\text {rest }}$ within the bursting population. Importantly, block of $\mathrm{K}_{\mathrm{ir}}$ channels unmasked rhythmic burst firing within newborn spinal pain circuits, suggesting that the ability to generate pacemaker activity may be a latent property of a significant number of SDH neurons during early life.

\section{$\mathrm{K}_{\mathrm{ir}}$ channels modulate passive membrane properties in neonatal SDH neurons}

Neurons with a relatively large $\mathrm{K}_{\mathrm{ir}}$ conductance are predicted to exhibit more negative resting potentials, lower $R_{\mathrm{m}}$, and minimal spontaneous activity (Hibino et al., 2010). As in other types of central neurons (Day et al., 2005; Young et al., 2009), $\mathrm{K}_{\mathrm{ir}}$ channels make a significant contribution to the resting leak conductance within newborn SDH neurons, as the level of $\mathrm{Ba}^{2+}$-sensitive $\mathrm{K}^{+}$ conductance was inversely correlated with $R_{\mathrm{m}}$ (Fig. $2 G$ ) and blocking $\mathrm{K}_{\mathrm{ir}}$ channels significantly elevated $R_{\mathrm{m}}$ in this population (Fig. $7 B$ ). As a result, the higher $R_{\mathrm{m}}$ and more depolarized $V_{\text {rest }}$ seen in lamina I pacemaker neurons (Fig. $1 B, C$ ) likely reflects, at least in part, a reduced conductance through $\mathrm{Ba}^{2+}$-sensitive $\mathrm{K}_{\mathrm{ir}}$ channels (Fig. 2E). Given that the prevalence of pacemaker activity significantly decreases after the first postnatal week ( $\mathrm{Li}$ and Baccei, 2011), it will be interesting to determine whether $\mathrm{K}_{\mathrm{ir}}$ currents are developmentally upregulated in lamina I neurons.

The available evidence strongly suggests that classical $\mathrm{K}_{\mathrm{ir}}$ $\left(\mathrm{K}_{\mathrm{ir}} 2 . \mathrm{x}\right)$ channels underlie the $\mathrm{Ba}^{2+}$-sensitive $\mathrm{K}^{+}$currents observed in the neonatal SDH. First, the strong inward rectification (Fig. 2) and high $\mathrm{Ba}^{2+}$ sensitivity (Fig. 3) of the $\mathrm{K}_{\mathrm{ir}}$ currents point to the involvement of the $\mathrm{K}_{\mathrm{ir}} 2 . \mathrm{x}$ family (Preisig-Mülleret al., 2002; Schram et al., 2002) and are inconsistent with the described properties of other rectifying $\mathrm{K}^{+}$channels (Coetzee et al., 1999). Indeed, our results clearly demonstrate that $\mathrm{K}_{\mathrm{ir}} 2.1-2.3$ channels are found in immature SDH cells (Fig. 5). In addition, whereas GIRK $\left(\mathrm{K}_{\mathrm{ir}} 3 . \mathrm{x}\right)$ channels are also expressed within lamina I-II (Lüscher et al., 1997; Marker et al., 2005, 2006) and are highly sensitive to $\mathrm{Ba}^{2+}$ (Owen et al., 1999; Lancaster et al., 2000), we found no evidence that these channels were constitutively active in $\mathrm{SDH}$ neurons at this age. This implies that differences in GIRK expression between the pacemaker and nonpacemaker populations are unlikely to explain the lower $\mathrm{K}_{\mathrm{ir}}$ conductance seen in spontane- 
ously bursting neurons. Instead, the data collectively suggest that although rhythmic burst firing is suppressed in the majority of immature lamina I neurons, attributable in part to $\mathrm{K}_{\mathrm{ir}} 2 . \mathrm{x}$ channel activity, a subset of these cells possesses minimal $\mathrm{K}_{\mathrm{ir}} 2 . \mathrm{x}$ conductance near $V_{\text {rest }}$ and thus becomes endowed with the ability to generate pacemaker activity. Interestingly, genetic inhibition of $\mathrm{K}_{\mathrm{ir}} 2.1$ currents unleashes pacemaker activity in ventricular myocytes that were previously quiescent (Miake et al., 2002). However, it should be noted that low $\mathrm{K}_{\mathrm{ir}} 2$.x conductance by itself is insufficient to generate rhythmic burst firing, as other channels such as persistent voltage-gated $\mathrm{Na}^{+}$channels and highthreshold voltage-gated $\mathrm{Ca}^{2+}$ channels are critically involved ( $\mathrm{Li}$ and Baccei, 2011). Lamina I neurons that failed to exhibit pacemaker activity after extracellular $\mathrm{Ba}^{2+}$ application may lack sufficient levels of these other ionic conductances.

\section{Potential mechanisms underlying low $\mathrm{K}_{\mathrm{ir}}$ conductance in spinal pacemaker neurons}

The mechanistic basis for the reduced $\mathrm{K}_{\mathrm{ir}}$ conductance within the pacemaker population remains to be determined. However, the data suggest that it does not result from an absence of particular $\mathrm{K}_{\mathrm{ir}} 2 . \mathrm{x}$ isoforms, as $\mathrm{K}_{\mathrm{ir}} 2.1, \mathrm{~K}_{\mathrm{ir}} 2.2$, and $\mathrm{K}_{\mathrm{ir}} 2.3$ were expressed in lamina I neurons exhibiting spontaneous burst firing (Fig. 5). Although $\mathrm{K}_{\mathrm{ir}} 2.4$ expression was not examined, the high $\mathrm{Ba}^{2+}$ sensitivity of the isolated $\mathrm{K}_{\mathrm{ir}}$ currents (Fig. 3) argues against a dominant expression of this isoform within the immature $\mathrm{SDH}$, as $\mathrm{K}_{\mathrm{ir}} 2.4$ is reported to show significantly lower $\mathrm{Ba}^{2+}$ sensitivity compared with other $\mathrm{K}_{\mathrm{ir}} 2$.x channels (Töpert et al., 1998; Coetzee et al., 1999). In fact, previous studies in the adult rat SDH suggest $\mathrm{K}_{\mathrm{ir}} 2.4$ expression is weaker compared with other $\mathrm{K}_{\mathrm{ir}} 2 . \mathrm{x}$ channels (Prüss et al., 2005).

The low $\mathrm{K}_{\mathrm{ir}}$ conductance in pacemaker neurons is also unlikely to be explained by a lower number of $\mathrm{K}_{\mathrm{ir}} 2$.x channels in the somatodendritic membrane compared with other lamina I cells, since the conductance was similar between the two groups at more negative potentials (Fig. $2 E$, right). Alternatively, since $\mathrm{K}_{\mathrm{ir}}$ subunits can form heteromultimers (Fink et al., 1996; PreisigMülleret al., 2002), it is feasible that bursting neurons express $\mathrm{K}_{\mathrm{ir}}$ channels with a distinct stoichiometry. $\mathrm{K}_{\mathrm{ir}} 2$.x isoforms that show similarly high sensitivity to $\mathrm{Ba}^{2+}$ may nonetheless exhibit varying degrees of inward rectification and possess different susceptibilities to block by intracellular polyamines (Dhamoon et al., 2004; Ishihara and Yan, 2007), which are normally present in cells at up to millimolar concentrations (Tabor and Tabor, 1984; Watanabe et al., 1991). Therefore, the higher $R_{\mathrm{m}}$ (Fig. $1 B$ ), more depolarized $V_{\text {rest }}$ (Fig. $1 C$ ), and greater $\mathrm{K}_{\mathrm{ir}}$ inward rectification (Fig. $2 F$ ) that characterize pacemaker neurons could reflect the preferential expression of $\mathrm{K}_{\mathrm{ir}}$ isoforms that are more sensitive to internal polyamine block. One potential candidate is $\mathrm{K}_{\mathrm{ir}} 2.2$, which has been associated with both extremely strong inward rectification and increased polyamine sensitivity compared with other $\mathrm{K}_{\mathrm{ir}} 2 . \mathrm{x}$ channels (Panama and Lopatin, 2006; Ishihara and Yan, 2007).

Another possibility is that elevated intracellular levels of polyamines predispose a subset of SDH neurons to exhibit the high $R_{\mathrm{m}}$ required for the generation of rhythmic burst firing. The polyamines spermine and spermidine block $\mathrm{K}_{\mathrm{ir}}$ channels with a much higher (10- to 100-fold) potency than $\mathrm{Mg}^{2+}$ (Lopatin et al., 1994; Fakler et al., 1995) and are highly expressed within lamina I of the spinal cord (Laube et al., 2002), where they are synthesized from the amino acids arginine and methionine via the activation of ornithine decarboxylase (Tabor and Tabor, 1984). Interestingly, ornithine decarboxylase expression in the rat brain is highest at birth and declines rapidly during the first week of life (Pujic et al.,
1995). In addition, polyamine levels in the CNS can be modulated by sensory experience during development (Aizenman et al., 2002). Alternatively, it is also feasible that pacemaker neurons are distinguished by differences in $\mathrm{Mg}^{2+}$ transport or buffering, which result in elevated intracellular concentrations of free $\mathrm{Mg}^{2+}$. Large changes in internal $\mathrm{Mg}^{2+}$ levels can occur in response to both hormonal and nonhormonal stimuli (Romani and Scarpa, 2000; Shindo et al., 2011), including alterations in cAMP levels or PKC activity (for review, see Romani, 2007). This raises the possibility that the enhanced rectification seen in pacemakers is explained by a greater block of $\mathrm{K}_{\mathrm{ir}}$ channels by intracellular $\mathrm{Mg}^{2+}$ at membrane potentials positive to $E_{\mathrm{K}}$.

Nonetheless, the pronounced difference in $\mathrm{K}^{+}$conductance between pacemakers and nonpacemakers at physiological potentials (Fig. 2) may also reflect the contribution of additional ion channels that act preferentially at potentials positive to $E_{\mathrm{K}}$. For example, some subtypes of voltage-gated $\mathrm{K}^{+}$channels, including members of the $\mathrm{K}_{\mathrm{v}} 3 . \mathrm{x}$ and $\mathrm{K}_{\mathrm{v}} 7 . \mathrm{x}$ (KCNQ) families, can be open near $V_{\text {rest }}$ (Schroeder et al., 2000; Abbott et al., 2001). Therefore, the higher $R_{\mathrm{m}}$ within the pacemaker population (Fig. 1) could be partially explained by a lower resting conductance through constitutively active voltage-gated $\mathrm{K}^{+}$channels.

\section{$\mathrm{K}_{\mathrm{ir}}$ channels as putative targets of neuromodulators within newborn spinal nociceptive circuits}

Although we failed to observe constitutive activation of GIRK $\left(\mathrm{K}_{\mathrm{ir}} 3 . \mathrm{x}\right)$ channels in the neonatal SDH in vitro, previous work suggests that GIRK channels can be opened by metabotropic receptors such as the $\mathrm{GABA}_{\mathrm{B}} \mathrm{R}$ from birth (Baccei and Fitzgerald, 2004). Thus, the level of endogenous burst firing within the immature SDH may, under certain conditions, be under tight metabotropic control as previously reported in the deep dorsal horn of the adult (Derjean et al., 2003). One prominent candidate is the NK1 receptor that is expressed in the dorsal horn from the first days of life (Kar and Quirion, 1995; Cheunsuang et al., 2002), as substance $P$ is known to regulate pacemaker activity in other regions of the CNS (Peña and Ramirez, 2004).

It should be noted that classical $\mathrm{K}_{\mathrm{ir}} 2$.x channels are also influenced by intracellular signaling cascades. For example, PKC and src kinase significantly inhibit $\mathrm{K}_{\mathrm{ir}} 2.2$ channels (Zitron et al., 2004, 2008). Notably, both PKC and src activity are elevated in the dorsal horn under pathological conditions (Guo et al., 2004; Kawasaki et al., 2004; Liu et al., 2008), suggesting that the prevalence of pacemaker activity within developing spinal nociceptive circuits might be modulated by nerve or tissue injury. Indeed, peripheral nerve damage during adulthood significantly increases the percentage of deep dorsal horn neurons that exhibit plateau potentials (Reali et al., 2011). An excessive number of pacemakers after injury could result in abnormal synchronization of firing within the SDH network, thereby significantly facilitating the output of the spinal pain pathway.

Further elucidation of the molecular properties that distinguish intrinsically bursting neurons within the newborn SDH will yield insight into potential strategies to selectively manipulate their excitability in vivo, which may then reveal the precise role of spinal pacemaker activity in the maturation of central nociceptive circuits.

\section{References}

Abbott GW, Butler MH, Bendahhou S, Dalakas MC, Ptacek LJ, Goldstein SA (2001) MiRP2 forms potassium channels in skeletal muscle with Kv3.4 
and is associated with periodic paralysis. Cell 104:217-231. CrossRef Medline

Aizenman CD, Muñoz-Elías G, Cline HT (2002) Visually driven modulation of glutamatergic synaptic transmission is mediated by the regulation of intracellular polyamines. Neuron 34:623-634. CrossRef Medline

Baccei ML, Fitzgerald M (2004) Development of GABAergic and glycinergic transmission in the neonatal rat dorsal horn. J Neurosci 24:4749-4757. CrossRef Medline

Blankenship AG, Feller MB (2010) Mechanisms underlying spontaneous patterned activity in developing neural circuits. Nat Rev Neurosci 11:1829. CrossRef Medline

Borodinsky LN, Root CM, Cronin JA, Sann SB, Gu X, Spitzer NC (2004) Activity-dependent homeostatic specification of transmitter expression in embryonic neurons. Nature 429:523-530. CrossRef Medline

Brocard F, Tazerart S, Vinay L (2010) Do pacemakers drive the central pattern generator for locomotion in mammals? Neuroscientist 16:139-155. CrossRef Medline

Chen X, Johnston D (2005) Constitutively active G-protein-gated inwardly rectifying $\mathrm{K}^{+}$channels in dendrites of hippocampal CA1 pyramidal neurons. J Neurosci 25:3787-3792. CrossRef Medline

Cheunsuang O, Maxwell D, Morris R (2002) Spinal lamina I neurones that express neurokinin 1 receptors: II. Electrophysiological characteristics, responses to primary afferent stimulation and effects of a selective muopioid receptor agonist. Neuroscience 111:423-434. CrossRef Medline

Coetzee WA, Amarillo Y, Chiu J, Chow A, Lau D, McCormack T, Moreno H, Nadal MS, Ozaita A, Pountney D, Saganich M, Vega-Saenz de ME, Rudy B (1999) Molecular diversity of K+ channels. Ann N Y Acad Sci 868: 233-285. CrossRef Medline

Day M, Carr DB, Ulrich S, Ilijic E, Tkatch T, Surmeier DJ (2005) Dendritic excitability of mouse frontal cortex pyramidal neurons is shaped by the interaction among HCN, Kir2, and Kleak channels. J Neurosci 25:87768787. CrossRef Medline

Del Negro CA, Koshiya N, Butera RJ Jr, Smith JC (2002) Persistent sodium current, membrane properties and bursting behavior of pre-botzinger complex inspiratory neurons in vitro. J Neurophysiol 88:2242-2250. CrossRef Medline

Derjean D, Bertrand S, Le Masson G, Landry M, Morisset V, Nagy F (2003) Dynamic balance of metabotropic inputs causes dorsal horn neurons to switch functional states. Nat Neurosci 6:274-281. CrossRef Medline

Dhamoon AS, Pandit SV, Sarmast F, Parisian KR, Guha P, Li Y, Bagwe S, Taffet SM, Anumonwo JM (2004) Unique Kir2.x properties determine regional and species differences in the cardiac inward rectifier $\mathrm{K}+$ current. Circ Res 94:1332-1339. CrossRef Medline

Fakler B, Brändle U, Glowatzki E, Weidemann S, Zenner HP, Ruppersberg JP (1995) Strong voltage-dependent inward rectification of inward rectifier $\mathrm{K}+$ channels is caused by intracellular spermine. Cell 80:149-154. CrossRef Medline

Fink M, Duprat F, Heurteaux C, Lesage F, Romey G, Barhanin J, Lazdunski M (1996) Dominant negative chimeras provide evidence for homo and heteromultimeric assembly of inward rectifier $\mathrm{K}+$ channel proteins via their N-terminal end. FEBS Lett 378:64-68. CrossRef Medline

Fleidervish IA, Libman L, Katz E, Gutnick MJ (2008) Endogenous polyamines regulate cortical neuronal excitability by blocking voltage-gated $\mathrm{Na}+$ channels. Proc Natl Acad Sci U S A 105:18994-18999. CrossRef Medline

Goldstein SA, Bockenhauer D, O'Kelly I, Zilberberg N (2001) Potassium leak channels and the KCNK family of two-P-domain subunits. Nat Rev Neurosci 2:175-184. CrossRef Medline

Gonzalez-Islas C, Wenner P (2006) Spontaneous network activity in the embryonic spinal cord regulates AMPAergic and GABAergic synaptic strength. Neuron 49:563-575. CrossRef Medline

Graham BA, Brichta AM, Callister RJ (2008) Recording temperature affects the excitability of mouse superficial dorsal horn neurons, in vitro. J Neurophysiol 99:2048-2059. CrossRef Medline

Grudt TJ, Perl ER (2002) Correlations between neuronal morphology and electrophysiological features in the rodent superficial dorsal horn. J Physiol 540:189-207. CrossRef Medline

Guo W, Wei F, Zou S, Robbins MT, Sugiyo S, Ikeda T, Tu JC, Worley PF, Dubner R, Ren K (2004) Group I metabotropic glutamate receptor NMDA receptor coupling and signaling cascade mediate spinal dorsal horn NMDA receptor $2 \mathrm{~B}$ tyrosine phosphorylation associated with inflammatory hyperalgesia. J Neurosci 24:9161-9173. CrossRef Medline
Hanson MG, Milner LD, Landmesser LT (2008) Spontaneous rhythmic activity in early chick spinal cord influences distinct motor axon pathfinding decisions. Brain Res Rev 57:77-85. CrossRef Medline

Hibino H, Inanobe A, Furutani K, Murakami S, Findlay I, Kurachi Y (2010) Inwardly rectifying potassium channels: their structure, function, and physiological roles. Physiol Rev 90:291-366. CrossRef Medline

Ishihara K, Yan DH (2007) Low-affinity spermine block mediating outward currents through Kir2.1 and Kir2.2 inward rectifier potassium channels. J Physiol 583:891-908. CrossRef Medline

Jin W, Lu Z (1998) A novel high-affinity inhibitor for inward-rectifier K+ channels. Biochemistry 37:13291-13299. CrossRef Medline

Kar S, Quirion R (1995) Neuropeptide receptors in developing and adult rat spinal cord: an in vitro quantitative autoradiography study of calcitonin gene-related peptide, neurokinins, mu-opioid, galanin, somatostatin, neurotensin and vasoactive intestinal polypeptide receptors. J Comp Neurol 354:253-281. CrossRef Medline

Kawasaki Y, Kohno T, Zhuang ZY, Brenner GJ, Wang H, Van Der Meer C, Befort K, Woolf CJ, Ji RR (2004) Ionotropic and metabotropic receptors, protein kinase A, protein kinase $\mathrm{C}$, and Src contribute to C-fiberinduced ERK activation and cAMP response element-binding protein phosphorylation in dorsal horn neurons, leading to central sensitization. J Neurosci 24:8310-8321. CrossRef Medline

Lancaster MK, Dibb KM, Quinn CC, Leach R, Lee JK, Findlay JB, Boyett MR (2000) Residues and mechanisms for slow activation and Ba2+ block of the cardiac muscarinic $\mathrm{K}+$ channel, Kir3.1/Kir3.4. J Biol Chem 275: 35831-35839. CrossRef Medline

Laube G, Bernstein HG, Wolf G, Veh RW (2002) Differential distribution of spermidine/spermine-like immunoreactivity in neurons of the adult rat brain. J Comp Neurol 444:369-386. CrossRef Medline

Leao RM, Li S, Doiron B, Tzounopoulos T (2012) Diverse levels of an inwardly rectifying potassium conductance generate heterogeneous neuronal behavior in a population of dorsal cochlear nucleus pyramidal neurons. J Neurophysiol 107:3008-3019. CrossRef Medline

Li J, Baccei ML (2011) Pacemaker neurons within newborn spinal pain circuits. J Neurosci 31:9010-9022. CrossRef Medline

Light AR, Perl ER (1979) Spinal termination of functionally identified primary afferent neurons with slowly conducting myelinated fibers. J Comp Neurol 186:133-150. CrossRef Medline

Liu GX, Derst C, Schlichthörl G, Heinen S, Seebohm G, Brüggemann A, Kummer W, Veh RW, Daut J, Preisig-Müller R (2001) Comparison of cloned Kir2 channels with native inward rectifier $\mathrm{K}+$ channels from guinea-pig cardiomyocytes. J Physiol 532:115-126. CrossRef Medline

Liu XJ, Gingrich JR, Vargas-Caballero M, Dong YN, Sengar A, Beggs S, Wang SH, Ding HK, Frankland PW, Salter MW (2008) Treatment of inflammatory and neuropathic pain by uncoupling Src from the NMDA receptor complex. Nat Med 14:1325-1332. CrossRef Medline

Lopatin AN, Makhina EN, Nichols CG (1994) Potassium channel block by cytoplasmic polyamines as the mechanism of intrinsic rectification. Nature 372:366-369. CrossRef Medline

Lorenzo LE, Ramien M, St Louis M, De Koninck Y, Ribeiro-da-Silva A (2008) Postnatal changes in the Rexed lamination and markers of nociceptive afferents in the superficial dorsal horn of the rat. J Comp Neurol 508:592-604. CrossRef Medline

Lu Z, MacKinnon R (1994) Electrostatic tuning of Mg2+ affinity in an inward-rectifier K+ channel. Nature 371:243-246. CrossRef Medline

Lüscher C, Jan LY, Stoffel M, Malenka RC, Nicoll RA (1997) G proteincoupled inwardly rectifying $\mathrm{K}+$ channels (GIRKs) mediate postsynaptic but not presynaptic transmitter actions in hippocampal neurons. Neuron 19:687-695. CrossRef Medline

Marker CL, Luján R, Loh HH, Wickman K (2005) Spinal G-protein-gated potassium channels contribute in a dose-dependent manner to the analgesic effect of mu- and delta- but not kappa-opioids. J Neurosci 25:35513559. CrossRef Medline

Marker CL, Luján R, Colon J, Wickman K (2006) Distinct populations of spinal cord lamina II interneurons expressing G-protein-gated potassium channels. J Neurosci 26:12251-12259. CrossRef Medline

Matsuda H, Saigusa A, Irisawa H (1987) Ohmic conductance through the inwardly rectifying $\mathrm{K}$ channel and blocking by internal $\mathrm{Mg} 2+$. Nature 325:156-159. CrossRef Medline

Miake J, Marban E, Nuss HB (2002) Biological pacemaker created by gene transfer. Nature 419:132-133. CrossRef Medline

Owen JM, Quinn CC, Leach R, Findlay JB, Boyett MR (1999) Effect of ex- 
tracellular cations on the inward rectifying $\mathrm{K}+$ channels Kir2.1 and Kir3.1/Kir3.4. Exp Physiol 84:471-488. CrossRef Medline

Panama BK, Lopatin AN (2006) Differential polyamine sensitivity in inwardly rectifying Kir2 potassium channels. J Physiol 571:287-302. CrossRef Medline

Pearson HA, Dolphin AC (1993) Inhibition of omega-conotoxin-sensitive $\mathrm{Ca} 2+$ channel currents by internal Mg2 + in cultured rat cerebellar granule neurones. Pflugers Arch 425:518-527. CrossRef Medline

Peña F, Ramirez JM (2004) Substance P-mediated modulation of pacemaker properties in the mammalian respiratory network. J Neurosci 24: 7549-7556. CrossRef Medline

Preisig-Müller R, Schlichthörl G, Goerge T, Heinen S, Brüggemann A, Rajan S, Derst C, Veh RW, Daut J (2002) Heteromerization of Kir2.x potassium channels contributes to the phenotype of Andersen's syndrome. Proc Natl Acad Sci U S A 99:7774-7779. CrossRef Medline

Prüss H, Derst C, Lommel R, Veh RW (2005) Differential distribution of individual subunits of strongly inwardly rectifying potassium channels (Kir2 family) in rat brain. Brain Res Mol Brain Res 139:63-79. CrossRef Medline

Pujic Z, Matsumoto I, Wilce PA (1995) Expression of the genes coding for ornithine decarboxylase and its regulatory protein antizyme in the developing rat brain. Dev Neurosci 17:286-291. CrossRef Medline

Ramirez JM, Tryba AK, Peña F (2004) Pacemaker neurons and neuronal networks: an integrative view. Curr Opin Neurobiol 14:665-674. CrossRef Medline

Reali C, Fossat P, Landry M, Russo RE, Nagy F (2011) Intrinsic membrane properties of spinal dorsal horn neurones modulate nociceptive information processing in vivo. J Physiol 589:2733-2743. CrossRef Medline

Robinson RB, Siegelbaum SA (2003) Hyperpolarization-activated cation currents: from molecules to physiological function. Annu Rev Physiol 65:453-480. CrossRef Medline

Romani A (2007) Regulation of magnesium homeostasis and transport in mammalian cells. Arch Biochem Biophys 458:90 -102. CrossRef Medline

Romani AM, Scarpa A (2000) Regulation of cellular magnesium. Front Biosci 5:D720-D734. CrossRef Medline

Safronov BV, Pinto V, Derkach VA (2007) High-resolution single-cell imaging for functional studies in the whole brain and spinal cord and thick tissue blocks using light-emitting diode illumination. J Neurosci Methods 164:292-298. CrossRef Medline

Schoenmakers TJ, Visser GJ, Flik G, Theuvenet AP (1992) CHELATOR: an improved method for computing metal ion concentrations in physiological solutions. Biotechniques 12:870-874, 876-879. Medline

Schram G, Melnyk P, Pourrier M, Wang Z, Nattel S (2002) Kir2.4 and Kir2.1 $\mathrm{K}(+)$ channel subunits co-assemble: a potential new contributor to inward rectifier current heterogeneity. J Physiol 544:337-349. CrossRef Medline

Schroeder BC, Waldegger S, Fehr S, Bleich M, Warth R, Greger R, Jentsch TJ (2000) A constitutively open potassium channel formed by KCNQ1 and KCNE3. Nature 403:196-199. CrossRef Medline

Shin J, Shen F, Huguenard JR (2005) Polyamines modulate AMPA receptor-dependent synaptic responses in immature layer v pyramidal neurons. J Neurophysiol 93:2634-2643. CrossRef Medline

Shindo Y, Fujii T, Komatsu H, Citterio D, Hotta K, Suzuki K, Oka K (2011) Newly developed $\mathrm{Mg} 2+$-selective fluorescent probe enables visualization of $\mathrm{Mg} 2+$ dynamics in mitochondria. PLoS One 6:e23684. CrossRef Medline

Sugiura Y, Lee CL, Perl ER (1986) Central projections of identified, unmyelinated (C) afferent fibers innervating mammalian skin. Science 234: 358-361. CrossRef Medline

Szucs P, Pinto V, Safronov BV (2009) Advanced technique of infrared LED imaging of unstained cells and intracellular structures in isolated spinal cord, brainstem, ganglia and cerebellum. J Neurosci Methods 177:369380. CrossRef Medline

Tabor CW, Tabor H (1984) Polyamines. Annu Rev Biochem 53:749-790. CrossRef Medline

Takigawa T, Alzheimer C (2002) Phasic and tonic attenuation of EPSPs by inward rectifier $\mathrm{K}+$ channels in rat hippocampal pyramidal cells. J Physiol 539:67-75. CrossRef Medline

Tazerart S, Viemari JC, Darbon P, Vinay L, Brocard F (2007) Contribution of persistent sodium current to locomotor pattern generation in neonatal rats. J Neurophysiol 98:613-628. CrossRef Medline

Tazerart S, Vinay L, Brocard F (2008) The persistent sodium current generates pacemaker activities in the central pattern generator for locomotion and regulates the locomotor rhythm. J Neurosci 28:8577-8589. CrossRef Medline

Töpert C, Döring F, Wischmeyer E, Karschin C, Brockhaus J, Ballanyi K, Derst C, Karschin A (1998) Kir2.4: a novel K+ inward rectifier channel associated with motoneurons of cranial nerve nuclei. J Neurosci 18:4096-4105. Medline

Tritsch NX, Yi E, Gale JE, Glowatzki E, Bergles DE (2007) The origin of spontaneous activity in the developing auditory system. Nature 450:50 55. CrossRef Medline

Watanabe S, Kusama-Eguchi K, Kobayashi H, Igarashi K (1991) Estimation of polyamine binding to macromolecules and ATP in bovine lymphocytes and rat liver. J Biol Chem 266:20803-20809. Medline

Yoshimura M, Jessell TM (1989) Membrane properties of rat substantia gelatinosa neurons in vitro. J Neurophysiol 62:109-118. Medline

Young CC, Stegen M, Bernard R, Müller M, Bischofberger J, Veh RW, Haas CA, Wolfart J (2009) Upregulation of inward rectifier K+ (Kir2) channels in dentate gyrus granule cells in temporal lobe epilepsy. J Physiol 587:4213-4233. CrossRef Medline

Zitron E, Kiesecker C, Lück S, Kathöfer S, Thomas D, Kreye VA, Kiehn J, Katus HA, Schoels W, Karle CA (2004) Human cardiac inwardly rectifying current IKir2.2 is upregulated by activation of protein kinase A. Cardiovasc Res 63:520-527. CrossRef Medline

Zitron E, Günth M, Scherer D, Kiesecker C, Kulzer M, Bloehs R, Scholz EP, Thomas D, Weidenhammer C, Kathöfer S, Bauer A, Katus HA, Karle CA (2008) Kir2.x inward rectifier potassium channels are differentially regulated by adrenergic alpha1A receptors. J Mol Cell Cardiol 44:84-94. CrossRef Medline 